\title{
Tinnitus Patients Suffering from Anxiety and Depression: A Review
}

Kasra Ziai

Omid Moshtaghi ${ }^{1}$

Hossein Mahboubi ${ }^{1}$

Hamid R Djalilian²

\begin{abstract}
Objectives: To review literature on the link between depression and anxiety in patients suffering from tinnitus. Method: A systematic review of published English-language literature was performed using PubMed, Ovid, and Cochrane databases. Results: Of the 56 eligible abstracts 15 were chosen to be included in the review. All articles showed an association of depression and anxiety in tinnitus patients. Conclusions: Because of the strong association between tinnitus, depression, and anxiety- all tinnitus patients should be screened for psychiatric disorders. Treatment for these complex conditions should involve a multidisciplinary team with cognitive behavioral therapy and possible pharmacological therapy.
\end{abstract}

Keywords: tinnitus, depression, anxiety, stress.

'Division of Neurotology and Skull Base Surgery, Department of Otolaryngology-Head \& Neck, University of California, Irvine, CA. E-mail: kasra.ziaie@gmail.com / omoshtagh@uci.edu / hmahboub@uci.edu

${ }^{2}$ Division of Neurotology and Skull Base Surgery, Department of Otolaryngology-Head \& Neck Surgery and Biomedical Engineering, University of California, Irvine, CA.

E-mail: hdjalili@uci.edu

Institution: University of California, Irvine, USA

Send correspondence to:

Hamid R Djalilian

Professor of Otolaryngology and Biomedical Engineering, University of California, Irvine, Building 56, Room 500 Orange CA 92868, USA, E-mail: hdjalili@uci.edu

Paper submitted to the ITJ-EM (Editorial Manager System) on May 05, 2017;

and accepted on June 09, 2017. 


\section{INTRODUCTION}

Tinnitus is defined as hearing a sound in the absence of an external auditory origin. Its constant noise can be irritating and extremely distressing, with $0.5 \%$ experiencing symptoms so severe that they are no longer able to lead a normal life ${ }^{1}$. Latest figures estimate $9.6 \%$ of the population experienced tinnitus within 1 year $^{2}$. The bothersome nature of tinnitus has lead to an association with psychiatric diseases including depression and anxiety. Depression and anxiety already have high prevalence, independent of tinnitus with rates estimated to be $6.7 \%$ and $15.2-28.7 \%$ respectively ${ }^{3,4,5}$.

With each of these disorders being reported as an independent disease processes, the possibility of these existing as comorbid conditions has been brought to the forefront. Major depression has been described in up to $33 \%$ of patients with tinnitus ${ }^{6}$. Anxiety is also closely associated and can be seen in up to $45 \%$ of patients with tinnitus $^{7}$. The high prevalence of tinnitus, anxiety and depression, warrants a review of literature to shed light on the link between these diseases.

Because there is no objective test for tinnitus, clinicians must rely on questionaries' to assess the severity of the disease ${ }^{8}$. The most commonly used instrument is the tinnitus handicap inventory (THI) which determines the perceived impact of symptom's ${ }^{9}$. Anxiety and depression are instead psychiatric disorders, with the diagnosis made by fulfilling DSM V criteria clinically ${ }^{10}$. The most commonly used metric used in depression are the Becks depression inventory (BDI) and State Trait Anxiety Inventory for anxiety ${ }^{11,12}$. By using these instruments to measure tinnitus, depression, and anxiety we aim to review the literature to describe how these 3 conditions can occur together.

\section{METHODS}

A thorough literature search of published Englishlanguage literature was performed in PubMed, Ovid, and Cochrane databases using the keywords ("tinnitus" AND "depression" AND "anxiety"). A total of 295 abstracts were primarily identified. All abstracts were evaluated with 56 eligible abstracts identified based on our inclusion criteria. The authors reviewed each of the 56 papers independently for selection. If disagreement between manuscript inclusions occurred, the final decision was made by the lead researcher (H.R.D). Case studies and letters to editors were excluded from this review. A total of 15 papers were selected of the 56 .

\section{RESULTS}

The composition of the 15 studies includes 11 cross-sectional and 4 case-control studies (Table 1). The most common instrument used to measure tinnitus severity was Tinnitus Handicap Inventory (THI) $(n=7)$. Other instruments used were Visual Analogue Scale $(n=$ $1)$, Tinnitus reaction questionnaire $(n=1)$, and Subjective Tinnitus Severity Scale $(n=1)$. One study used both THI and Tinnitus reaction questionnaire to assess tinnitus ${ }^{13}$.

Evaluation of patients for anxiety, depression and other psychiatric disorders include; Beck Depression Inventory $(\mathrm{n}=4)$, State Trait Anxiety Inventory $(\mathrm{n}=$ 5), Symptom Check List-90-Revised $(n=2)$, Hospital Anxiety and Depression Scale $(n=2)$, and Beck Anxiety Inventory $(n=2)$. Other survey instruments used were Depressive Tendency Questionnaire (DTQ), IIIness Attitude Scale, Obsessive Beliefs Questionnaire-44 (OBQ44), International Statistical Classification of Diseases 9 (ICD-9), Depression, Anxiety and Stress Scale, and Mini International Neuropsychiatric Interview ${ }^{13-23}$.

A strong correlation between tinnitus, anxiety and depression was determined in 12 of 13 studies reviewed. Bartels et al. evaluated 256 patients suffering from tinnitus and divided them into 4 groups; no-symptoms, anxietyonly, depression-only, and anxiety and depression ${ }^{13}$. A statistically higher association between tinnitus and psychiatric comorbidities were observed in anxiety and depression group (39.2\%) compared to anxiety-only (10.2\%) and depression-only (9.8\%) groups.

Trevis et al. evaluated 81 patients with chronic tinnitus for depression and anxiety disorders ${ }^{14}$. Of the study cohort, $28 \%$ of patients suffered from depression and $95 \%$ of patients suffered from anxiety disorders. It was also demonstrated that depression has an indirect effect of on anxiety and tinnitus suggesting that depression is the casual factor in the comorbid conditions. Bhatt et al. conducted a cross-sectional analysis using a national health survey ${ }^{24}$. It was determined that there is a high prevalence of depression (25.6\%) and anxiety $(26.1 \%)$ in those with tinnitus. They also identified aggravating factors in tinnitus patients compared to controls, including fewer hours of sleep ( 7.00 vs. $7.21 ; P<0.001)$ and on average more work days missed (6.94 vs. $3.79, \mathrm{P}<0.001)$.

Kehrle et al. evaluated 84 patients suffering from tinnitus and compared them to 47 individuals without tinnitus ${ }^{15}$. Depression and anxiety were assessed with Beck Depression Inventory and Beck Anxiety Inventory respectively. In the study group, $35(41.7 \%)$ patients had depression, and 41 (48.8\%) had anxiety symptoms. In contrast, the control group had 2 (4.25\%) patients suffering from depression while none had anxiety proving statistical significant difference between the. All patients exhibited a direct correlation between tinnitus annoyance and severity depression and anxiety. In another study by Halford et al., it was suggested that the severity of tinnitus highly correlates with the likelihood of patients developing anxiety and derpression ${ }^{25}$. They evaluated 112 patients for tinnitus severity using STSS, depression using DTQ and anxiety using STAI. They concluded that there's a significant correlation between STSS scores and DTQ and STAI scores.

Sullivan et al. conducted a Case-control study on 40 patients suffering from tinnitus and 14 control individuals suffering from hearing loss with no associated tinnitus ${ }^{26}$. 
Table 1. Summary of the 15 studies included in this review.

\begin{tabular}{|c|c|c|c|c|c|c|c|c|c|c|}
\hline Authors & $\begin{array}{l}\text { Study } \\
\text { design }\end{array}$ & $\begin{array}{l}\text { Sample } \\
\text { size }\end{array}$ & $\begin{array}{l}\text { Age } \\
\text { (years) }\end{array}$ & $\begin{array}{l}\text { Male/ } \\
\text { Female (\%) }\end{array}$ & $\begin{array}{l}\text { Tinnitus } \\
\text { Measures }\end{array}$ & $\begin{array}{l}\text { Anxiety } \\
\text { disorders } \\
\text { measures }\end{array}$ & $\begin{array}{l}\text { Anxiety } \\
\text { disorders } \\
\text { (\%) }\end{array}$ & $\begin{array}{l}\text { Depression } \\
\text { disorder } \\
\text { measures }\end{array}$ & $\begin{array}{l}\text { Depressive } \\
\text { disorders (\%) }\end{array}$ & Main results \\
\hline $\begin{array}{l}\text { Trevis et } \\
\text { al. }^{14}\end{array}$ & $\begin{array}{l}\text { Cross- } \\
\text { sectional }\end{array}$ & 81 & $18-82$ & $43 / 57$ & THI & $\begin{array}{l}\text { STAI, IAS, } \\
\text { OBQ-44 }\end{array}$ & 95 & BDI & 28 & $\begin{array}{l}\text { Strong relationship } \\
\text { between tinnitus, } \\
\text { depression and } \\
\text { anxiety disorders }\end{array}$ \\
\hline $\begin{array}{l}\text { Kehrle et } \\
\text { al. } .^{15}\end{array}$ & $\begin{array}{l}\text { Case- } \\
\text { control }\end{array}$ & 84 & $18-48$ & $45.2 / 54.8$ & THI & BAI & 48.80 & $\mathrm{BDI}$ & $\begin{array}{l}41.7 \% \text { in the } \\
\text { sample vs. } \\
4.3 \% \text { in the } \\
\text { control group }\end{array}$ & $\begin{array}{l}\text { Strong correlation } \\
\text { between tinnitus } \\
\text { annoyance } \\
\text { depression and } \\
\text { anxiety level }\end{array}$ \\
\hline $\begin{array}{l}\text { Bhatt et } \\
\text { al. }{ }^{24}\end{array}$ & $\begin{array}{l}\text { Cross- } \\
\text { sectional }\end{array}$ & $\begin{array}{l}21.4 \\
\text { million }\end{array}$ & - & - & $\begin{array}{l}\text { Self- } \\
\text { reported }\end{array}$ & Self-reported & 26.10 & Self-reported & 25.60 & $\begin{array}{l}\text { Tinnitus is strongly } \\
\text { associated with } \\
\text { depression, anxiety, } \\
\text { greater work days } \\
\text { missed and shorter } \\
\text { sleep hours }\end{array}$ \\
\hline $\begin{array}{l}\text { McCor- } \\
\text { mack et } \\
\text { al. }{ }^{48}\end{array}$ & $\begin{array}{l}\text { Cross- } \\
\text { sectional }\end{array}$ & $1,71,728$ & $40-69$ & $54 / 46$ & $\begin{array}{l}\text { UK } \\
\text { Biobank }\end{array}$ & UK Biobank & 88 & UK Biobank & 88 & $\begin{array}{l}\text { Strong correlation } \\
\text { between tinnitus, } \\
\text { depression and } \\
\text { anxiety }\end{array}$ \\
\hline Hu et al. ${ }^{16}$ & $\begin{array}{l}\text { Cross- } \\
\text { sectional }\end{array}$ & 91 & $\begin{array}{l}\text { Mean } \\
\text { age: } 64\end{array}$ & $100 / 0$ & THI & ICD-9 codes & 79.10 & ICD-9 codes & 59.30 & $\begin{array}{l}58.2 \% \text { of patients } \\
\text { suffered from } \\
\text { both anxiety and } \\
\text { depression }\end{array}$ \\
\hline $\begin{array}{l}\text { Gu } \square \text { l et } \\
\text { al. }{ }^{77}\end{array}$ & $\begin{array}{l}\text { Case- } \\
\text { control }\end{array}$ & 100 & $\begin{array}{l}\text { Mean } \\
\text { age: } \\
43.14\end{array}$ & $52 / 48$ & - & $\begin{array}{l}\text { ASI-3, STAI- } \\
\text { 2, SCL-90-R } \\
\text { GSI, SCL- } \\
\text { 90-R So- } \\
\text { matization, } \\
\text { SCL-90-R } \\
\text { Anxiety, SCL- } \\
\text { 90-R Phobic } \\
\text { Anxiety }\end{array}$ & - & $\begin{array}{l}\text { SCL-90-R } \\
\text { Depression }\end{array}$ & - & $\begin{array}{l}\text { Chronic tinnitus } \\
\text { is associated with } \\
\text { higher prevalence } \\
\text { of psychiatric } \\
\text { diseases } \\
\text { (depression, } \\
\text { anxiety, somatoform } \\
\text { disorder) }\end{array}$ \\
\hline $\begin{array}{l}\text { Adoga et } \\
\text { al. }{ }^{18}\end{array}$ & $\begin{array}{l}\text { Cross- } \\
\text { sectional }\end{array}$ & 49 & 22- 79 & $55.1 / 44.9$ & - & $\begin{array}{l}\text { HADS; } \\
\text { RAND-36 } \\
\text { item health } \\
\text { survey } 1.0 \\
\text { question- } \\
\text { naires. } \\
\end{array}$ & 69.30 & $\begin{array}{l}\text { HADS; } \\
\text { RAND-36 } \\
\text { item health } \\
\text { survey } 1.0 \\
\text { question- } \\
\text { naires. } \\
\end{array}$ & 51 & $\begin{array}{l}\text { Strong relationship } \\
\text { between tinnitus } \\
\text { and psychological } \\
\text { disorders }\end{array}$ \\
\hline $\begin{array}{l}\text { Gomma et } \\
\text { al. }{ }^{49}\end{array}$ & $\begin{array}{l}\text { Cross- } \\
\text { sectional }\end{array}$ & 100 & $20-60$ & $60 / 40$ & VAS & DASS & $\begin{array}{l}83.3 \% \text { of } \\
\text { female } \\
\text { patients, } \\
90 \% \text { of male } \\
\text { patients }\end{array}$ & DASS & $\begin{array}{l}90 \% \text { in } \\
\text { patients aged } \\
20-39,80 \% \text { in } \\
\text { patients aged } \\
40-60\end{array}$ & $\begin{array}{l}\text { The level of } \\
\text { anxiety in patients } \\
\text { with tinnitus is } \\
\text { associated with the } \\
\text { duration of tinnitus. }\end{array}$ \\
\hline $\begin{array}{l}\text { Udupi et } \\
\text { al. }{ }^{19}\end{array}$ & $\begin{array}{l}\text { Cross- } \\
\text { sectional }\end{array}$ & 50 & $19-60$ & $38 / 62$ & THI & STAI & - & $\begin{array}{l}\text { Inventory of } \\
\text { Depressive } \\
\text { Symptom- } \\
\text { atology-Self } \\
\text { Report-30 }\end{array}$ & 80 & $\begin{array}{l}\text { Strong relationship } \\
\text { between tinnitus, } \\
\text { anxiety and } \\
\text { depression }\end{array}$ \\
\hline $\begin{array}{l}\text { Cho } \\
\text { et al. }^{20}\end{array}$ & $\begin{array}{l}\text { Cross- } \\
\text { sectional }\end{array}$ & 104 & $\begin{array}{l}\text { Mean } \\
\text { age: } 51\end{array}$ & $54 / 46$ & THI & STAI & 32 & BDI & 57 & $\begin{array}{l}\text { Moderate to severe } \\
\text { tinnitus has high } \\
\text { correlation with } \\
\text { depression and } \\
\text { anxiety }\end{array}$ \\
\hline $\begin{array}{l}\text { Marciano } \\
\text { et } \mathrm{al}^{22}\end{array}$ & $\begin{array}{l}\text { Cross- } \\
\text { sectional }\end{array}$ & 75 & - & $40 / 60$ & THI & MINI & 29 & MINI & - & $\begin{array}{l}77 \% \text { of the patients } \\
\text { tinnitus patients } \\
\text { suffer from a } \\
\text { psychiatric disorder }\end{array}$ \\
\hline Belli et al. ${ }^{23}$ & $\begin{array}{l}\text { Case- } \\
\text { control }\end{array}$ & 180 & $19-60$ & $54.4 / 46.6$ & - & $\begin{array}{l}\text { BAI, SCL- } \\
90-R\end{array}$ & 24.40 & $\begin{array}{l}\text { BDI, SCL- } \\
90-R\end{array}$ & 56 & $\begin{array}{l}\text { Psychiatric } \\
\text { disorders such as } \\
\text { anxiety, depression } \\
\text { and somatoform } \\
\text { disorders were } \\
\text { significantly higher } \\
\text { in the tinnitus group } \\
\text { vs. control group. }\end{array}$ \\
\hline
\end{tabular}




\begin{tabular}{|c|c|c|c|c|c|c|c|c|c|c|}
\hline $\begin{array}{l}\text { Bartels et } \\
\text { al. }^{13}\end{array}$ & $\begin{array}{l}\text { Cross- } \\
\text { sectional }\end{array}$ & 256 & $\begin{array}{l}\text { Mean } \\
\text { age: } \\
55.38\end{array}$ & $30.2 / 69.8$ & $\begin{array}{l}\text { THI, Tin- } \\
\text { nitus reac- } \\
\text { tion ques- } \\
\text { tionnaire }\end{array}$ & HADS & 10.20 & HADS & 9.80 & $\begin{array}{l}39.2 \% \text { of the } \\
\text { patients suffered } \\
\text { from anxiety plus } \\
\text { depression. There } \\
\text { was a significant } \\
\text { correlation between } \\
\text { tinnitus and anxiety } \\
\text { plus depression } \\
\text { group }\end{array}$ \\
\hline $\begin{array}{l}\text { Halford et } \\
\text { al. }{ }^{25}\end{array}$ & $\begin{array}{l}\text { Cross- } \\
\text { sectional }\end{array}$ & 112 & $29-87$ & $\begin{array}{l}57 / 39(4 \\
\text { unstated } \\
\text { sex })\end{array}$ & STSS & STAI & - & DTQ & - & $\begin{array}{l}\text { Significant } \\
\text { correlation between } \\
\text { STSS, STAI and } \\
\text { DTQ scores }\end{array}$ \\
\hline $\begin{array}{l}\text { Sullivan et } \\
\text { al. }{ }^{26}\end{array}$ & $\begin{array}{l}\text { Case- } \\
\text { control }\end{array}$ & 54 & - & - & - & - & - & $\begin{array}{l}\text { SCL90, } \\
\text { Chronic } \\
\text { illness } \\
\text { Problem } \\
\text { Inventory, } \\
\text { Revised } \\
\text { Ways of } \\
\text { Coping } \\
\text { Checklist. }\end{array}$ & 78 & $\begin{array}{l}\text { A significant } \\
\text { correlation between } \\
\text { tinnitus and } \\
\text { depression }\end{array}$ \\
\hline
\end{tabular}

THI: Tinnitus Handicap Inventory; STAI: State Trait Anxiety Inventory; IAS: Illness Attitudes Scale; OBQ-44: Obsessive Beliefs Questionnaire; BDI: Beck Depression Inventory; BAI: Beck Anxiety Inventory; ICD-9: International Statistical Classification of Diseases; ASI: Anxiety Sensitivity Index; SCL90-R: Symptom Check List-90-Revised; GSI: Global Symptom Index; HADS: Hospital Anxiety and Depression Scale; VAS: Visual Analogue Scale; DASS: Depression, Anxiety and Stress Scale; MINI: Mini International Neuropsychiatric Interview; STSS: Subjective Tinnitus Severity Scale; DTQ: Depressive Tendency Questionnaire

Hopkins Symptom Checklist (SCL-90), the Chronic Illness Problem Inventory, and the Revised Ways of Coping Checklist were used to assess the patients for affective disorders. $78 \%$ of tinnitus patients suffered from lifetime major depression compared to $21 \%$ of the control group. Also, $60 \%$ of the tinnitus patients suffered from current depression compared to $7 \%$ of the control group.

\section{CONCLUSION}

This review shows mounting evidence supporting the association of tinnitus with depression and anxiety. It is challenging to establish the causality of tinnitus and its role on these psychological disorders. The added burden of tinnitus can often exacerbate existing or advance depression and anxiety. In turn, these patients could be more sensitive to stressors and can perceive tinnitus to be worse when compared to the rest of the population.

There is a large discrepancy between the rate of depression (9.8-90\%) and anxiety disorders (10.2-95\%) that can be attributed to different measures and scales used to classify the patients in different studies. In addition, one study ${ }^{23}$ had a significantly lower prevalence of anxiety and depression compared to the general population. This significantly skews the range. Most of the studies showed that between $50-90 \%$ of patients suffered from anxiety or depression. Sex, age and ethnicity did not seem to play a major role in this discrepancy. We believe that the methodology of tinnitus studies should be unified such that the same scales are used for depression and anxiety.

Substantial research has been devoted to exploring the molecular relationship between tinnitus in the context of anxiety and depression. Some propose a neurobiological basis for the overlap suggesting the limbic system- responsible for functions including emotions and behavior- as a possible explanation. Evidence shows widespread activation of the limbic system in tinnitus and anxiety patients, establishing a potential connection to auditory system ${ }^{27-29}$. An alternative theory suggests tinnitus is related to psychological disorders through a cortisol mediator. Existence of glucocorticoid receptors in the inner ear has been proven, coupled with evidence that tinnitus patients have high cortisol levels ${ }^{30,31}$. Correspondingly, patients with anxiety and depression also exhibit higher levels of cortisol, leading to the possibility of a positive feedback loop exacerbating tinnitus ${ }^{32}$. This evidence provides proof that a central mechanism is at play linking anxiety and depression in patients with tinnitus. The instruments used to show tinnitus improvement, highly correlate with those used for depression and anxiety. Thus, a reasonable clinical intervention includes treatment with antidepressants. Many medications have been used in the treatment of tinnitus patient's suffering from anxiety and depression and include; TCAs, SSRIs, antipsychotics, mood stabilizers, benzodiazepines, and glutamate receptor antagonists ${ }^{33}$.

Medications have been shown to have variable success with no strong evidence showing superior efficacy of any one antidepressant ${ }^{34,35}$. Nortripyline, has had mixed results with two randomized placebo based studies resulting in a decrease in depressive and tinnitus symptoms when compared to the placebo group ${ }^{36,37}$ while another suggests no difference between placebo ${ }^{38}$. 38 Benzodiazepines have also been used, and continue to be the most commonly prescribed medication for tinnitus, despite its substantial risk of dependence ${ }^{39,40}$. Clonazapam has shown improvement in tinnitus in one study ${ }^{41}$, while another study suggests clonazepam is only effective when used in combination with Deanxit ${ }^{42}$. In contrast, one clinical trial determined no efficacy with 
Alprazolam use $\mathrm{e}^{43}$. SSRI treatment has also been shown to be effective in treating both tinnitus and depression ${ }^{44}$. Most notably, the use of SSRI's in non-depressed tinnitus patients has not shown any benefit, further illustrating the interconnected relationship between tinnitus and depression ${ }^{45}$. Effective non-medical options also exist, most notable cognitive behavioral therapy (CBT). Use of CBT has been validated as a treatment of anxiety and depression for decades ${ }^{46}$, and is has recently been added to the American Academy of otolaryngologyhead and neck surgery guideline for tinnitus treatment ${ }^{8}$. Because of its proven success in treating each condition independently, use for anxiety and depression in tinnitus has been shown to be highly effective ${ }^{47}$.

An abundance of evidence illustrates that many tinnitus patients are concurrent suffering from anxiety and depression. With this in mind, a psychological assessment screening for these conditions is fully warranted in the work up of a tinnitus patient. Once a psychological diagnosis is made, a treatment plan that addresses tinnitus alone can be considered inadequate. This review shows that if effective control of anxiety and depression is achieved, tinnitus can be improved as well. Yet, further neurobiological research needs to be done to better elucidate the relationship between these two comorbid conditions and develop specific treatments that are unique to this patient population ${ }^{48,49}$. Lastly, clinicians treating this cohort of patients should be encourage to participate in an inter disciplinary teams from different specialties to provide a comprehensive treatment addressing all aspects of this complicated disease process.

\section{REFERENCES}

1. Davis A, Eraeot ITR, editor, Tinnitus handbook. San Diego, CA: Singular Publishing Group; 2000.

2. Bhatt JM, Lin HW, Bhattacharyya N. Prevalence, Severity, Exposures, and Treatment Patterns of Tinnitus in the United States. JAMA Otolaryngol Head Neck Surg. 2016;142(10):959-65.

3. Kessler RC, Chiu WT, Demler O, Merikangas KR, Walters EE. Prevalence, severity, and comorbidity of 12-month DSM-IV disorders in the National Comorbidity Survey Replication. Arch Gen Psychiatry. 2005;62(6):617-27.

4. Kessler RC, Anthony JC, Blazer DG, Eaton WW, Kendler K, Swartz $M$, et al. The US National Comorbidity Survey: overview and future directions. Epidemiologia e psichiatria sociale. 1997;6(1):4-16.

5. Turner RJ, Gil AG. Psychiatric and substance use disorders in South Florida: racial/ethnic and gender contrasts in a young adult cohort. Arch Gen Psychiatry. 2002;59(1):43-50.

6. Zoger S, Svedlund J, Holgers KM. Relationship between tinnitus severity and psychiatric disorders. Psychosomatics. 2006;47(4):282-8.

7. Zoger S, Svedlund J, Holgers KM. Psychiatric disorders in tinnitus patients without severe hearing impairment: 24 month follow-up of patients at an audiological clinic. Audiology. 2001;40(3):133-140.

8. Tunkel DE, Bauer CA, Sun GH, Rosenfeld RM, Chandrasekhar SS, Cunningham ER Jr, et al. Clinical practice guideline: tinnitus. Otolaryngol Head Neck Surg. 2014;151(2 Suppl):S1-40.

9. Newman CW, Sandridge SA, Jacobson GP. Psychometric adequacy of the Tinnitus Handicap Inventory (THI) for evaluating treatment outcome. J Am Acad Audiol. 1998;9(2):153-60.

10.American Psychiatric A. Diagnostic and statistical manual of mental disorders (DSM-5®). American Psychiatric Pub; 2013.
11.Beck AT, Epstein N, Brown G, Steer RA. An inventory for measuring clinical anxiety: psychometric properties. J Consult Clin Psychol. 1988;56(6):893-7 .

12.Spielberger CD. State-Trait anxiety inventory. Wiley Online Library; 2010.

13. Bartels H, Middel BL, van der Laan BF, Staal MJ, Albers FW. The additive effect of co-occurring anxiety and depression on health status, quality of life and coping strategies in help-seeking tinnitus sufferers. Ear Hear. 2008;29(6):947-56.

14. Trevis KJ, McLachlan NM, Wilson SJ. Psychological mediators of chronic tinnitus: The critical role of depression. J Affect Disord. 2016;204:234-40.

15. Kehrle HM, Sampaio AL, Granjeiro RC, de Oliveira TS, Oliveira CA. Tinnitus Annoyance in Normal-Hearing Individuals: Correlation With Depression and Anxiety. Ann Otol Rhinol Laryngol. 2016;125(3):185-94.

16. Hu J, Xu J, Streelman M, Xu H, Guthrie O. The Correlation of the Tinnitus Handicap Inventory with Depression and Anxiety in Veterans with Tinnitus. Int J Otolaryngol. 2015;2015:689375.

17.Gul Al, Ozkiris M, Aydin R, Simsek G, Saydam L. Coexistence of anxiety sensitivity and psychiatric comorbidities in patients with chronic tinnitus. Neuropsychiatr Dis Treat. 2015;11:413-8.

18. Adoga AA, Kokong DD, Nimkur TL, Okwori ET. The impact of tinnitus on adult Nigerians: health related Quality of Life assessment of sufferers using the Hospital Anxiety and Depression Scale (HADS) and the RAND-36 item health survey 1.0 questionnaire. Int Tinnitus J. 2015;19(2):26-32.

19.Udupi VA, Uppunda AK, Mohan KM, Alex J, Mahendra MH. The relationship of perceived severity of tinnitus with depression, anxiety, hearing status, age and gender in individuals with tinnitus. Int Tinnitus J. 2013;18(1):29-34.

20. Cho CG, Chi JH, Song JJ, Lee EK, Kim BH. Evaluation of anxiety and depressive levels in tinnitus patients. Korean J Audiol. 2013;17(2):83-9.

21. Langguth B, Landgrebe M, Kleinjung T, Sand GP, Hajak G. Tinnitus and depression. World J Biol Psychiatry. 2011;12(7):489-500.

22. Marciano E, Carrabba L, Giannini P, Sementina C, Verde P, Bruno C, et al. Psychiatric comorbidity in a population of outpatients affected by tinnitus: Comorbilidad psiquiátrica en una población de pacientes de consulta externa afectados por tinnitus. Int J Audiol. 2009;42(1):4-9.

23. Belli S, Belli H, Bahcebasi T, Ozcetin A, Alpay E, Ertem U. Assessment of psychopathological aspects and psychiatric comorbidities in patients affected by tinnitus. Eur Arch Otorhinolaryngol. 2008;265(3):279-85.

24. Bhatt JM, Bhattacharyya N, Lin HW. Relationships between tinnitus and the prevalence of anxiety and depression. Laryngoscope. 2017;127(2):466-9.

25. Halford JB, Anderson SD. Anxiety and depression in tinnitus sufferers. J Psychosom Res. 1991;35(4-5):383-90.

26. Sullivan MD, Katon W, Dobie R, Sakai C, Russo J, Harrop-Griffiths J. Disabling tinnitus. Association with affective disorder. Gen Hosp Psychiatry. 1988;10(4):285-91.

27.Lockwood AH, Salvi RJ, Coad ML, Towsley ML, Wack DS, Murphy BW. The functional neuroanatomy of tinnitus: evidence for limbic system links and neural plasticity. Neurology. 1998;50(1):114-20.

28. MartinEI,ResslerKJ,BinderE,NemeroffCB.Theneurobiologyofanxiety disorders: brain imaging, genetics, and psychoneuroendocrinology. Psychiatr Clin North Am. 2009;32(3):549-75.

29. Etkin A, Wager TD. Functional neuroimaging of anxiety: a metaanalysis of emotional processing in PTSD, social anxiety disorder, and specific phobia. Am J Psychiatry. 2007;164(10):1476-88.

30. Rarey KE, Curtis LM. Receptors for glucocorticoids in the human inner ear. Otolaryngol Head Neck Surg. 1996;115(1):38-41.

31. Hebert S, Paiement P, Lupien SJ. A physiological correlate for the intolerance to both internal and external sounds. Hear Res. 2004;190(1-2):1-9.

32. Yehuda R, Boisoneau D, Mason JW, Giller EL. Glucocorticoid receptor number and cortisol excretion in mood, anxiety, and psychotic disorders. Biol Psychiatry. 1993;34(1-2):18-25. 
33. Belli H, Belli S, Oktay MF, Ural C. Psychopathological dimensions of tinnitus and psychopharmacologic approaches in its treatment. Gen Hosp Psychiatry. 2012;34(3):282-9.

34. Robinson SK, Viirre ES, Stein MB. Antidepressant therapy in tinnitus. Hear Res. 2007;226(1-2):221-31.

35.Langguth $\mathrm{B}$, Elgoyhen $\mathrm{AB}$. Current pharmacological treatments for tinnitus. Expert Opin Pharmacother. 2012;13(17):2495-509.

36. Sullivan MD, Dobie RA, Sakai CS, Katon WJ. Treatment of depressed tinnitus patients with nortriptyline. Ann Otol Rhinol Laryngol. 1989;98(11):867-72.

37. Sullivan M, Katon W, Russo J, Dobie R, Sakai C. A randomized trial of nortriptyline for severe chronic tinnitus. Effects on depression, disability, and tinnitus symptoms. Arch Intern Med. 1993;153(19):2251-9.

38.Dobie RA, Sakai CS, Sullivan MD, Katon WJ, Russo J. Antidepressant treatment of tinnitus patients: report of a randomized clinical trial and clinical prediction of benefit. Am J Otol. 1993;14(1):18-23.

39. Owen RT, Tyrer P. Benzodiazepine dependence. A review of the evidence. Drugs. 1983;25(4):385-98.

40.Daftary A, Shulman A, Strashun AM, Gottschalk C, Zoghbi SS, Seibyl JP. Benzodiazepine receptor distribution in severe intractable tinnitus. Int Tinnitus J. 2004;10(1):17-23.

41. Han SS, Nam EC, Won JY, et al. Clonazepam quiets tinnitus: a randomised crossover study with Ginkgo biloba. J Neurol Neurosurg Psychiatry. 2012;83(8):821-7.
42. Meeus $O$, De Ridder D, Van de Heyning P. Administration of the combination clonazepam-Deanxit as treatment for tinnitus. Otol Neurotol. 2011;32(4):701-9.

43. Jalali MM, Kousha A, Naghavi SE, Soleimani R, Banan R. The effects of alprazolam on tinnitus: a cross-over randomized clinical trial. Med Sci Monit. 2009;15(11):Pi55-60.

44.Zoger S, Svedlund J, Holgers KM. The effects of sertraline on severe tinnitus suffering- A randomized, double-blind, placebo-controlled study. J Clin Psychopharmacol. 2006;26(1):32-9.

45.Robinson SK, Viirre ES, Bailey KA, Gerke MA, Harris JP, Stein MB. Randomized placebo-controlled trial of a selective serotonin reuptake inhibitor in the treatment of nondepressed tinnitus subjects. Psychosom Med. 2005;67(6):981-8.

46.Spek V, Cuijpers PIM, Nyklícek I, Riper H, Keyzer J, Pop V. Internetbased cognitive behaviour therapy for symptoms of depression and anxiety: a meta-analysis. Psychol Med. 2007;37(03):319-28.

47. Andersson G. Psychological aspects of tinnitus and the application of cognitive behavioral therapy. Clin Psychol Rev. 2002;22(7):977-90.

48. McCormack A, Edmondson-Jones M, Fortnum H, Dawes PD, Middleton $\mathrm{H}$, Munro KJ, et al. Investigating the association between tinnitus severity and symptoms of depression and anxiety, while controlling for neuroticism, in a large middle-aged UK population. Int J Audiol. 2015;54(9):599-604.

49. Gomaa MA, Elmagd MH, Elbadry MM, Kader RM. Depression, Anxiety and Stress Scale in patients with tinnitus and hearing loss. Eur Arch Otorhinolaryngol. 2014;271(8):2177-84. 